Tersedia Online di http://journal.unismuh.ac.id/index.php/otoritas

Otoritas : Jurnal Ilmu Pemerintahan, 6 (2), Oktober 2016, 98-111

\title{
Islam, Media, dan Politik : Sebuah Perdebatan dan Kontempelasi Nilai Berdemokrasi
}

\author{
Idil Akbar*) \\ Departemen Ilmu Pemerintahan, Fakultas Ilmu Sosial dan Ilmu Politik Universitas Padjajaran \\ Jalan Raya Bandung Sumedang Km. 21, Jatinangor, Sumedang, Jawa Barat Indonesia \\ Diterima : 1 Juli 2016; Disetujui : 29 Agustus 2016; Dipublikasikan 14 Oktober 2016
}

\begin{abstract}
Infact, press or media is one of pilar democracy. Media in democracy is a public sphere to communication and makes relation, and a same time as public arena to gain information. But, media also could not release from streotypes and tendency that usually bring of interest, either the owner or ideology. It is meaning media can not released from perspective distorsion, values bias and take a side. Media also effective to become propaganda instrument for a political interest and an ideology. It is seen like how media in US, for example, stereotype of Islam in discourses contradiction and global interest opposition. Then, Islam dominantly identified as doctrine teaches radicalism, fundamentalism and terorism. Thus, it is often be justification for US to operate the military mission in the name of democracy.
\end{abstract}

Keywords: democracy; media and islam; political global; stereotype of islam

\begin{abstract}
Abstrak
Tak dipungkiri pers atau media menjadi salah satu pilar bagi demokrasi. Media dalam demokrasi adalah sebagai ruang bagi publik berkomunikasi dan berinteraksi, sekaligus sarana publik memperoleh informasi tentang banyak hal. Namun, media juga tak bisa dilepaskan dari stereotip dan kecenderungan-kecenderungan, yang biasanya membawa kepentingan, baik pemilik maupun ideologi. Media karenanya tak lepas dari distorsi perspektif, bias nilai dan berpihak. Media juga efektif menjadi alat propaganda bagi sebuah kepentingan politik dan ideologi, seperti bagaimana media di negara Amerika, misalnya, menstereotipkan Islam dalam analisis pertentangan wacana dan kepentingan global. Sehingga, dominan Islam diidentikkan dengan sematan sebagai ajaran yang mengajarkan radikalisme, fundamentalisme dan terorisme. Karenanya pula seringkali menjadi alasan pembenar bagi Amerika untuk menjalankan misi militer atas nama demokrasi.
\end{abstract}

Kata kunci : demokrasi; media dan islam; politik global; stereotip islam

Cara Penulisan Sitasi : Akbar, I. (2016). Islam, Media, dan Politik : Perdebatan dan Kontempleasi Nilai Berdemokrasi. Otoritas : Jurnal Ilmu Pemerintahan, 6(2), 98-111.

${ }^{*}$ Penulis Korespondensi.

E-Mail : idil.akbar@unpad.ac.id

Copyright (C) 2016, Otoritas : Jurnal Ilmu Pemerintahan, p-ISSN: 2088-3706, e-ISSN: 2502-9320 
Tersedia Online di http://journal.unismuh.ac.id/index.php/otoritas

Otoritas : Jurnal Ilmu Pemerintahan, 6 (2), Oktober 2016, 99

\section{Pendahuluan}

Membincangkan demokrasi seperti bumi yang berputar tanpa henti. Berbagai kerangka teoritik diperdebatkan bahkan dipertentangkan untuk menelaah demokrasi sebagai wacana ilmiah. Pun demokrasi sedemikian rupa diaplikasikan di berbagai negara, mencoba merasakan kenikmatan ideologi bernama demokrasi yang mungkin dapat dirasakan, sembari terus mencari bentuk terbaik bagi negara dan bangsa. Singkatnya, demokrasi bak "agama" yang dianut dan diyakini oleh banyak negara di dunia sebagai solusi ideologi terbaik, setidaknya hingga saat ini.

Era Renasissance di Eropa dianggap paling bertanggung jawab dalam melahirkan para pemikir politik revolusioner. Penting untuk mengingat kembali bahwa distorsi pemahaman berbasis pada empirisme (yang dirasakan dan dialami) dan filosofi (pengalaman intelektual) adalah bagian penting bagi para pemikir politik era ini dalam melahirkan varianvarian ideologi, salah satunya adalah demokrasi. Basis filsafat Plato dan Aristoteles di zaman Yunani Kuno, kemudian dilanjutkan Hobbes, Locke, Montesquieu hingga Rousseau, yang memandang masyarakat didirikan di atas pondasi politik. Baik itu berbentuk komunitas, seperti pemikiran Plato dan Aristoteles, atau kontrak sosial berdasarkan pembatasan dan ketakutan oleh Hobbes, maupun kontrak sosial berdasarkan kesepakatan ala Locke dan kehendak ala Rosseau (Latif, 2009), kesemuanya adalah konsepsi intelektual yang multidimensional, menembus batas negara dan tentunya berpengaruh.

Ide dasar dari demokrasi adalah kebebasan, baik itu kebebasan untuk hidup dan memiliki sebagaimana yang dijelaskan Locke (Suhelmi, 2007) dan juga kebebasan berpolitik (Montesquieu, 1993). Demokrasi adalah ketika semua orang mampu memperoleh dan menikmati hak-hak dasar. Ada lima kriteria universal untuk mengukur demokrasi
(Gaffar, 2000). Pertama, akuntabilitas, bahwa pejabat yang dipilih rakyat harus dapat mempertanggungjawabkan kebijaksanaan yang hendak dan telah ditempuhnya. Kedua, rotasi kekuasaan, bahwa terjadinya rotasi kekuasaan yang terus berjalan. Ketiga, rekrutmen politik terbuka, bahwa adanya rotasi kekuasaan menuntut diperlukannya sistem rekrutmen politik yang terbuka. Setiap orang akan diperlakukan sama. Keempat, pemilihan umum, bahwa pemilu harus dilakukan secara teratur dan setiap warga negara berhak untuk dipilih dan memilih. Kelima, menikmati hak-hak dasar, bahwa setiap warga masyarakat dapat menikmati hak-hak dasar mereka secara bebas, termasuk didalamnya adalah hak untuk menyatakan pendapat, hak untuk menikmati kebebasan pers, dan hak untuk berkumpul dan berserikat.

Mengacu pada kriteria kelima dari demokrasi tentang hak-hak dasar, salah satunya adalah hak berpendapat dan menikmati kebebasan pers, maka jika kita tarik dalam perbincangan yang lebih global, maka media (pers) menjadi salah satu instrumen penting di dalam mengukur demokratis tidaknya suatu negara. Bagi sebagian orang bahkan berpendapat, kebebasan pers adalah nafas dari demokrasi itu sendiri. Karena itu tak heran jika di negara-negara maju, kebebasan pers menjadi salah satu indikator terpenting di dalam menilai dinamika demokrasi yang berlangsung. Namun sedikit berbeda perlakuannya di negara-negara berkembang, dimana pers masih kerap terbelenggu oleh pembatasan dan pembredelan. Pers di banyak negara berkembang kerapkali dituding sebagai "pemicu konflik". Pers dengan demikian bukan dianggap sebagai pelembagaan resolusi konflik. Pers juga kerap dituding berpijak di landasan yang kontraproduktif dan konfrontatif, terutama mengenai gelombang kebenaran yang subjektif dan bias. Pertanyaannya benarkah demikian?

Ketika gelombang demokrasi melan- 
Tersedia Online di http://journal.unismuh.ac.id/index.php/otoritas

Otoritas : Jurnal Ilmu Pemerintahan, 6 (2), Oktober 2016, 100

da banyak negara paska perang dunia keII, pers (media) turut pula tumbuh subur. Kala itu, media berperan sebagai mediasi informal masyarakat untuk mengetahui apa yang terjadi. Namun seiring waktu, peran media berkembang lebih dari itu. Saat ini, peran media tidak sekedar menyampaikan informasi, namun juga berperan dalam mengidentifikasi, menginvestigasi dan bahkan mengagitasi opini publik. Media tidak sekedar berfungsi sebagai mediator warta, akan tetapi berfungsi pula sebagai kontrol sosial, check and balance, dan sebagainya.

Dampak dari kapitalisme global turut pula berpengaruh pada nilai yang dikandungnya. Tak pelak media "harus menyesuaikan" dengan kondisi dan situasi yang ada. Komersialisasi media tak terelakkan. Keadaan inilah yang menyebabkan media banyak diragukan independensinya. Penilaian ini disebabkan karena media sering berperan ganda, di satu sisi sebagai mediasi informasi bagi masyarakat, di sisi lain membawa misi tertentu, yakni terbentuknya sebuah opini, yang benar tidaknya sangat tergantung pada akseptabilitas masyarakat.

Di era globalisasi saat ini, peranan media, bahkan, sudah menjadi trendsetter atas kemajuan yang ada. Ini adalah realitas bahwa peran media sekarang dan untuk yang akan datang sungguh luar biasa. Seseorang yang bukanlah siapa-siapa sebelumnya, dengan dukungan media, dia menjadi seorang bintang yang bersinar. Di sisi lain, media bahkan juga berperan dalam mempengaruhi opini publik. Di Penyelenggaraan Pemilu di Indonesia, peran media digunakan sebagai sebagai sarana sosialisasi. Juga ketika AS dan sekutunya mencitrakan Islam dan negaranegara Islam sebagai teroris, banyak karena dipengaruhi oleh media. Sehingga dikemudian waktu terjadi pertentangan dan mistake of view terhadap Islam dan juga dunia Islam. Oleh media, Islam sering diindetikkan dengan kekerasan, penindasan, pemiskinan, dan terorisme. Begitu juga halnya dengan dunia Islam yang diwartakan banyak menyimpan potensi terorisme yang dapat mengancam kedamaian dunia. Edwar Said secara gamblang mendeskripsikan dalam bukunya bagaimana media dan para pakar menentukan cara pandang kita terhadap dunia, terutama dunia Islam. Mengenai tulisannya ini akan diulas dalam bab-bab berikutnya.

Namun, satu hal bahwa apapun bentuknya, media adalah bagian dari civil society yang dilekatkan pada tanggung jawab sosial dan moral, setidaknya sedikit mampu untuk konsisten menjalankan fungsi sosial. Civil society merupakan potensi akan selalu hadirnya keseimbangan diantara kekuasaan dan kekuatan yang ada.

Pengungkapan wacana demokrasi di atas dan bagaimana peran media serta civil society sebagai tolak ukur penting di dalam penerapan pemikiran ideologis, yakni demokrasi, maka pertanyaan penting yang dapat diajukan adalah bagaimana media memainkan perannya sebagai mediator informasi kepada masyarakat, baik terhadap masyarakat lokal maupun internasional, terhadap suatu masalah, melalui perspektif yang berkeadilan dan mengandung kebenaran. Tulisan ini akan coba difokuskan pula pada bagaimana perspektif media terhadap Islam dan dunia Islam, dengan membandingkan antara Indonesia dan Amerika Serikat. Terdapat beberapa alasan substansi mengenai mengapa membandingkan Indonesia dan Amerika mengenai ini, diantaranya karena transisi demokrasi yang terjadi saat ini di Indonesia dinilai banyak mengadopsi sistem demokrasi di Amerika Serikat dan tingginya kebebasan pers di Amerika pada akhirnya turut pula mempengaruhi pandangan dunia tentang terorisme dan Islam, dan pandangan Amerika terhadap Indonesia, sebab Indonesia adalah negara berpenduduk beragama Islam terbesar di dunia. 
Tersedia Online di http://journal.unismuh.ac.id/index.php/otoritas

Otoritas : Jurnal Ilmu Pemerintahan, 6 (2), Oktober 2016, 101

\section{Studi Literatur}

\subsection{Demokrasi dan demokratisasi}

Sesuai Hampir semua negara yang ada di dunia ini, baik monarki maupun republik mempunyai lembaga-lembaga yang dikenal sebagai perwujudan demokrasi. Walaupun keberadaan lembagalembaga itu tidak selalu menjamin adanya demokrasi, tetapi keberadaannya menjadikan suatu negara dan masyarakat didalamnya layak dianggap sebagai negara dan masyarakat yang beradab. Dengan kata lain, demokrasi menjadi sebuah preskripsi yang bermuatan nilai moral dan menjadi sebuah norma. Keberhasilan suatu bangsa dan suatu negara tidak hanya diukur dari neraca perekonomian, tingkat kesejahteraan dan pendidikan, tetapi juga diukur melalui seberapa jauh suatu bangsa dan negara melaksanakan demokrasi dengan bentuk tertentu dari demokrasi yang dianggap sebagai bentuk ideal sebagai patokan ukuran keberhasilan pelaksanaan demokrasi.

Untuk memahami demokrasi, ada dua pendekatan yang sering digunakan para ilmuwan politik. Pertama, secara normatif dimana demokrasi dipahami sebagai sesuatu yang secara ideal hendak dilakukan atau diselenggarakan oleh suatu negara (demokrasi diartikan sebagai tujuan atau resep tentang bagaimana demokrasi itu seharusnya). Pengertian umum ini dapat dilihat dari ungkapan bahwa demokrasi itu adalah pemerintahan oleh rakyat dari rakyat dan untuk rakyat. Kedua, secara empiris dimana demokrasi berkenaan dengan perwujudannya dalam kehidupan politik praktis dan sistem politik yang ada. Banyak teori tentang demokrasi itu berada pada tingkat normatif, sementara literatur tentang demokratisasi dicirikan oleh pendekatan empiris. Kriteria-kriteria untuk melihat sebuah bentuk pemerintahan demokratis atau tidak bersumber pada pendekatan empiris ini. Walaupun penerapan demokrasi di beberapa tempat melahirkan ben- tuk demokrasi yang beragam, akan tetapi ada kriteria universal yang berlaku bagi semua tempat yang melaksanakan demokrasi.

Memasuki era tahun 70-an, kecenderungan umum teorisasi demokrasi sejak tahun 1970-an adalah terjadinya kemerosotan pengaruh pemikiran tentang demokrasi yang "substantivist". Definisi demokrasi yang rasional, utopian dan ideal, yang mewarnai konseptualisasi pada masa sebelumnya, kehilangan banyak pengaruh. Teorisasi masa kini lebih menekankan persoalan prosedur, yaitu persoalan penciptaan prosedur. Tumpuannya adalah gagasan yang dilontarkan Joseph Schumpeter setengah abad lalu, yaitu demokrasi sebagai model politik. Menurut Schumpeter, yang oleh teori klasik disebut "kehendak rakyat" sebenarnya adalah hasil proses politik, bukan motor penggeraknya. Demokrasi atau metode demokratik menurut Schumpeter adalah Pengaturan kelembagaan untuk mencapai keputusan-keputusan politik di dalam mana individu-individu, melalui perjuangan memperebutkan suara rakyat terpilih, memproleh kekuasaan untuk membuat keputusan" (Mas'oed, 1994).

Definisi Schumpeterian yang lebih bersifat empirik, deskriptif, instutusional dan prosedural inilah yang mendominasi sejak 1970-an. Gagasan yang memandang demokrasi sebagai suatu sistem untuk memperoses konflik dimana partai yang kalah dalam Pemilu tidak berusaha merusak rezim demi mencapai tujuannya, tetapi bersedia menerima kenyataan dan menunggu putaran pertarungan dalam Pemilu berikutnya adalah gagasan Schumpeterian. Begitu juga konsepsi di Palma yang menyatakan bahwa demokrasi adalah gagasan koeksistensi menjadi cukup menarik bagi kelompokkelompok utama dalam masyarakat sehingga mereka bisa diajak bersepakat mengenai aturan-aturan dasar permainan. Definisi demokrasi yang 
Tersedia Online di http://journal.unismuh.ac.id/index.php/otoritas

Otoritas : Jurnal Ilmu Pemerintahan, 6 (2), Oktober 2016, 102

menekankan hak pilih universal dan pemerintahan mayoritas juga bersifat prosedural Schumpeterian (mas'oed, 1994).

Lebih dari tiga dekade lalu, Samuel Huntington menulis tentang masa depan demokrasi. Dirinya merasa pesimis akan akan keberlangsungan demokrasi dapat berjalan lancar disebabkan oleh terpaan krisis ekonomi yang berakibat pula pada krisis politik (Huntington dkk., 1975). Setidaknya terdapat tiga tantangan yang akan mengarah pada krisis demokrasi, pertama, tantangan intrinsic dari bagaimana demokrasi sejatinya berfungsi di dalam negeri, kedua, tantangan kontekstual, bagaimana implementasi demokrasi diadopsi dengan berbagai faktor seperti ekonomi, politik dan kebudayaan, dan ketiga,kelaikan demokrasi tergantung pada struktur sosial dan tren sosial yang bisa saja terguncang karena resources dan pengetahuan hanya beredar pada segelintir orang (elit). Tingkat korupsi yang tinggi dapat pula memicu terjadinya krisis demokrasi (Huntington dkk., 1975).

Demokrasi, demikian banyak pemimpin dunia menilai sebagai ideologi terbaik saat ini. Dan proses mendemokratisasikan negara-negara yang belum atau masih rendah tingkat demokrasinya adalah agenda politik, terutama oleh negara-negara maju seperti Amerika Serikat. Bahkan, anggapan bahwa demokratisasi pasti mendatangkan kebaikan telah menjadi dogma, terutama sebelum krisis ekonomi melanda dunia. Di masa kepemimpinan Presiden Bill Clinton, demokratisasi dijadikan sebagai dasar politik luar negeri AS. Mereka bersikukuh bahwa menyebarkan demokrasi berarti memperluas perdamaian.

Jack Synider, dalam bukunya berjudul From Voting to Violance: Democratization and Nationalist Conflict, mengungkapkan hal berbeda dari keyakinan umum. Menurutnya, sejarah selalu mencatat bahwa demokratisasi, tepatnya masa transisi menuju demokrasi sering menimbulkan kerusuhan SARA, perang, bahkan disintegrasi negara-bangsa. Perdamaian terpelihara hanya antara negara yang demokrasinya telah matang. Synder menegaskan bahwa konflik dan kerusuhan sebagai efek dari demokratisasi bukan hanya terjadi saat-saat ini, namun telah ada sejak berlangsungnya Revolusi Perancis tahun 1789. Keruntuhan tembok Berlin tahun 1989, Perang Irak-Iran tahun 1992, Krisis ekonomi 1997, kejatuhan WTC 2001 dan dilanjutkan dengan perang di Afganistan, Perang Irak di tahun 2003, dan lain-lain merupakan bagian dari upaya pelaksanaan demokrasi. Di Indonesia, demokratisasi yang berlangsung saat ini tak pernah usai. Bila mengacu pada kriteria-kriteria universal di atas, maka nampaknya demokratisasi di Indonesia masih akan berlangsung lama.

\subsection{Media dan Pembentukan Opini}

Jurgen Habermas dalam The Theory of Communicative Action mengungkapkan sebuah persepektif tentang "sistemdunia kehidupan" untuk menganalisis bagaimana kehidupan media. Menurutnya, media adalah perjumpaan antara rasionalitas komunikasi dan rasionalitas strategis. Pada satu sisi, media adalah institusi sosial yang memfasilitasi masyarakat dalam menjalankan diskursus sosial. Dalam negara hukum demokratis, media adalah struktur intermedier yang secara komunikatif menjembatani hak-hak politik - ekonomi warga negara dengan realitas penyelenggaraan kekuasaan. Media adalah ruang public politis yang berfungsi sebagai sistem, mengidentifikasi problem sosial serta memediasi keanekaragaman gaya hidup dan orientasi nilai dengan sistem politik (Habermas, 1989; Sudibyo, 2009).

Media dalam konteks ini adalah bagian dari kehidupan. Sebuah ruang simbolik tempat bersemainya "cakrawala" kesadaran, pemikiran, dan nilai-nilai ber- 
Tersedia Online di http://journal.unismuh.ac.id/index.php/otoritas

Otoritas : Jurnal Ilmu Pemerintahan, 6 (2), Oktober 2016, 103

sama dalam setiap tindak komunikasi yang saling memahami dan membentuk konsensus. Rasionalitas komunikatif media memegang peran kunci dalam mewujudkan kedaulatan publik atas totalitas bentuk dan isi komunikasi tentang persoalan-persoalan publik yang berlangsung, baik di dalam sistem politik maupun di tengah masyarakat luas. Media massa juga sering disebut sebagai cerminan masyarakat. Bukan hanya dalam arti tempat bagi masyarakat untuk dapat melihat diri sendiri, tetapi juga tempat pembentukan watak kultural masyarakat (Siregar, 2006).

Media merupakan organisasi, baik pemerintah maupun swasta, yang bertugas memberi informasi kepada publik. Di zaman modern, instrumen media meliputi koran, majalah, televisi, radio, dan lain sebagainya. Fungsi media cukup banyak, terdiri atas melaporkan fakta dan memberikan informasi, mendidik publik, memberi komentar, dan menyampaikan dan membentuk opini publik. Lebih jauh lagi, media juga berfungsi mengkritik, mengatur dan "mengontrol" pemerintah (termasuk polisi dan militer), serta pegawai negeri dan semua pelaku politik, kader partai yang terpilih maupun tidak terpilih, dan wakil LSM. Pendeknya, semua orang yang beraksi dalam lingkup publik. Karena itu, saat ini media merupakan faktor sentral dalam membentuk opini publik.

Opini publik merupakan pandangan orang banyak yang tidak terorganisasi, tersebar di mana-mana, dan karena kesamaan pandangan terhadap sesuatu, mereka secara sadar atau tidak dapat bergerak serentak dan bersatu-padu menyikapi sesuatu tersebut. Untuk itu, opini publik bisa diciptakan dan direncanakan. Seringkali - kalau tidak selalu - muatan berita sebuah media massa bermisi pembentukan opini publik. Jika sekarang lebih banyak orang memandang Usamah bin Ladin sebagai seorang teroris, hal itu karena tulisan yang membentuk opini pub- lik Usamah sebagai teroris lebih banyak dan dominan ketimbang tulisan yang menyanjungnya sebagai pejuang pembela Islam. Untuk membentuk opini publik, yang perlu dilakukan hanyalah mengintensifkan informasi yang harus sampai ke publik sesuai yang diinginkan.

Dalam mekanisme demokrasi, publik merupakan penguasa. Setiap keputusan-keputusan politik yang dihasilkan dan mengikat semua orang haruslah diketahui terlebih dahulu oleh publik (masyarakat). Publik tentunya akan merespon keputusan tersebut, apakah sesuai dengan aspirasi mereka atau tidak. Respon tersebut kemudian menjadi pedoman bagi para elit untuk memperbaiki keputusan yang mereka keluarkan, begitu seterusnya hingga masyarakat (publik) akan menerima keputusan tersebut. Terhadap semua itu, tentunya medialah yang berperan sebagai sarana perantara dalam menginformasikan semua keputusan yang dihasilkan elit dan untuk mendapatkan respon dari publik, agar terjadi kesempurnaan atas keputusan tersebut.

Sedemikian berpengaruhnya media saat ini dalam membentukopini publik. Dan inilah yang selama ini pula terus dilakukan oleh, terutama negara-negara maju seperti USA untuk mempropaganda apa -apa yang dapat mengancam kepentingan mereka. Dengan alasan menjaga keamanan nasional (National Security), mereka memainkan kepentingannya dalam membentuk opini dunia melalui media.

\subsection{Analisis media dan kebebasan in- formasi : Indonesia dan Amerika}

Salah satu hal yang mempengaruhi bagaimana kedudukan sebuah media, selain melalui analisa pemberitaan, yakni dengan mengetahui pemilik media tersebut. Preferensi the owner akan turut menjadi preferensi media dalam memberikan informasi kepada publik. Karena itu, analisis the owner menjadi penting untuk kita sajikan dalam tulisan ini, dengan 
Tersedia Online di http://journal.unismuh.ac.id/index.php/otoritas

Otoritas : Jurnal Ilmu Pemerintahan, 6 (2), Oktober 2016, 104

mengambil perbandingan antara media di Indonesia dan AS.

Di Amerika Serikat, media global adalah institusi yang menyediakan, memperoduksi dan mendistribusikan informasi, data, opini dan bahkan propaganda. Global berarti'menjangkau seluruh pelosok dunia'. Dan, media disinilah adalah 'lembaga atau perusahaan yang menjadi aktor dalam distribusi dan produksi informasi'.

Para aktor dalam media global terutama berasal dari AS, antara lain News Corporation milik Rupert Murdoch yang memiliki akses diberbagai media internasional. 132 surat kabar di Australia Inggris dan AS dimiliki News Corp. Dia juga adalah pemilik studio Twentieth Century Fox, penerbit buku Harper Collins, Asian Star television, British Sky Broadcasting. Selain itu, ia juga memiliki saham untuk Sky Television di Amerika Latin, India Channel V dan Phoenix Satellite Televison Company di Hongkong. Selain itu ada juga Time Warner, pemilik 24 majalah Time, penerbit buku kedua terbesar termasuk Time Life Books, Warner Music Group, Warner Brothers film studio, HBO, Cinemax, CNN dan Cartoon Network. Raksasa perusahan hiburan Disney yang memiliki studio Disney dan Buena Cista, dan lain-lain serta jaringan televisi ABC. Dan Viacom, pemilik 13 stasiun televisi di Amerika, jaringan televisi Global MTV, studi film Paramount, penerbit Simon \& Schuster, juga penerbit Macmillan. (Susilo, 2009).

Mengungkap bagaimana peran pemilik terhadap preferensi media menjadi sangat menarik ketika penguasaan terhadap informasi melahirkan sebuah dominasi dan hegemoni di media internasional. Penguasaan disini bukan hanya sekedar kelembagaan semata, namun juga penguasaan dalam materi informasi yang disampaikan. Sebagai contoh, bagaimana media memainkan materi antara fakta dan tujuan yang sebenarnya ketika Pemerintah AS menyerang Irak pada
Pemerintahan Bush. Nampak bahwa ada propaganda yang disampaikan untuk memberikan kesan (image) menyerang Irak di bawah Pemerintahan Saddam Husein adalah benar dan tepat, yakni menggulingkan pemerintahan yang otoriter dan menyebarkan paham demokrasi di negara tersebut. Penyebarluasan informasi dengan sudut pandang dan versi yang di-setting adalah upaya untuk menujukkan propaganda tersebut. Inilah salah satu kekuatan media di AS, yakni hegemoni informasi sebagai konsekuensi dari dominasi para pemilik terhadap media global, selain tingkat kebebasan informasi mereka yang juga cukup tinggi.

Di Indonesia, nama-nama seperti Surya Paloh lewat Media Group, Bakrie Group dan juga MNC Group adalah serentetan orang-orang dan lembaga yang menjadi the owner dari mayoritas pemilik media. Surya Paloh adalah pemilik jaringan televisi Metro TV dan Koran Media Indonesia. Kelompok Bakrie melalu pimpinan Aburizal Bakrie memiliki jaringan televisi ANteve dan TVone, serta beberapa media cetak. MNC Grup merupakan bagian dari jaringan televisi dan radio serta Koran Sindo di bawah kepemilikan Tanusudibyo. Selain itu, ada pula media berpengaruh lain seperti Kompas, majalah dan koran Tempo, Gatra, dan lain sebagainya. Dua nama seperti Surya Paloh dan Aburizal Bakrie adalah mereka yang juga memiliki keterlibatan langsung di politik. Sehingga agak sumir untuk dapat membedakan bahwa informasi yang disampaikan di dalam pemberitaan di media-media yang mereka miliki tidak mengandung materi kepentingan.

Tanpa harus menjadi pemuja Amerika yang menginspirasi dalam demokrasi dan kebebasan informasi di Indonesia, kita bisa menyaksikan dan sekaligus belajar bahwa kepercayaan pada kekuatan "kebebasan informasi" merupakan salah satu rahasia yang mendonamisasi bangsa Amerika hadir sebagai superpower. Sekitar 200 tahun lalu, ketika dihadapkan pa- 
Tersedia Online di http://journal.unismuh.ac.id/index.php/otoritas

Otoritas : Jurnal Ilmu Pemerintahan, 6 (2), Oktober 2016, 105

da dua pilihan antara "pemerintah tanpa surat kabar" di satu ekstrim, dan "surat kabar tanpa pemerintah" di ekstrim yang lain, Thomas Jefferson tanpa sedikit keraguan memilih pilihan kedua - surat kabar tanpa pemerintah; sebuah pilihan yang mengungkap relasi kekuasaan negaramasyarakat yang menempatkan negara pada posisi yang minimalis. Di Amerika, spirit kebebasan informasi secara tegas tertuang di dalam konstitusi AS pada amandemen pertama Bill of Right. Hal ini sekaligus membuktikan adanya kebebasan informasi bagi sistem kemasyarakatan dan politik. Selain itu, Undangundang tentang kebebasan informasi, Freedom of Information Act (FOIA) 1966, memberikan landasan konstitusional yang semakin kuat sekaligus instrument legal baru bagi para jurnalis AS untuk mendapatkan informasi mengenai kegiatan pemerintah. Kegiatan para jurnalis ini dijamin haknya untuk mendapatkan informasi yang bersifat bukan rahasia negara - dari segi kepentingan keamanan nasional Amerika. Karena itu, tak heran jika media di AS menjadi pilar keempat dalam sistem politik di AS (Lay, 2006).

Transisi demokrasi di Indonesia tidak menjadikan pilihan sulit bagi penyelenggaraan kebebasan informasi, meski itu sulit menjadi realitas di era orde baru. Kebijakan orde baru yang otoriter menghalangi terselenggaranya pers yang bebas dan independen. Namun, di masa setelahnya untunglah pers kembali mendapat tempat sebagaimana mestinya. Soal kebebasan informasi, UUD 1945 sebetulnya menjamin hal ini sebagaimana tertera berdasarkan pasal 28. Disini artinya negara menjamin hak para warganya dalam mengeluarkan pendapat, mendapat informasi dan berorganisasi. Dan kondisi tersebut diperkuat dengan adanya UU keterbukaan informasi dimana pemerintah dan seleuruh perangkatnya di daerah wajib melaporkan dan menginformasikan apa-apa yang ingin diketahui oleh masyarakat, sepanjang itu bukan bagian dari rahasia negara.

Persoalan kebebasan informasi dan juga bagaimana sebuah informasi dapat dinikmati oleh seluruh masyarakat, tak lepas dari bagaimana sistem politik berjalan di suatu negara, mulai dari mengenai sistem pemerintahan yang sedang berjalan misalnya apakah otoriter atau tidak, demokratis atau tidak, sentralistis, represif, dan sebagainya. Chilcote menjelaskan bahwa masyarakat biasanya dipandang sebagai entitas yang paling lengkap dimana sistem-sistem di dalamnya dapat di evaluasi. Sistem dengan demikian merupakan abstraksi msyarakat yang sebenarnya. Fenomena masyarakat apapun dapat dipandang sebagai satu atau sejumlah sistem. Dalam kenyataannya seluruh fenomena sosial saling berkaitan, meskipun batas-batas (boundaries) dapat diterapkan untuk menggambarkan sistem-sistem yang berbeda, misalnya sistem politik, ekonomi, sosial dan psikologi budaya (Chilcote, 2007).

Bagaimana sebuah sistem ini berjalan, perlu mengingat kembali kerangka dasar yang diungkapkan oleh David Easton tentang teori sistem. Menurut Easton, konsep-konsep kekuasaan, pengambilan keputusan, kewenangan, dan kebijakan adalah esensi dalam gagasan kehidupan politik. Identifikasi sistem itu sendiri meliputi empat hal, pertama, sifat-sifat identifikasi dalam bentuk unit dan batas-batas, kedua, input dan output, ketiga, pembedaan dalam sistem, dan empat, integrasi di dalam sistem.

Secara sederhana, dalam sistem berlaku klausa umum yakni adanya sirkulasi dari setiap kebijakan, pengambilan keputusan dan kewenangan yang dilakukan oleh penguasa. Hal tersebut bersumber dari masukan (input), baik berupa data maupun aspirasi, kemudian diproses dalam sebuah sistem politik, setelah itu akan terdapat keluaran (output) berupa keputusan, kebijaksanaan, dan sebagainya. Namun, sebuah sistem tidaklah 
Tersedia Online di http://journal.unismuh.ac.id/index.php/otoritas

Otoritas : Jurnal Ilmu Pemerintahan, 6 (2), Oktober 2016, 106

statis. Ada pengaruh dari lingkungan yang berfungsi mendorong, melakukan tekanan, ataupun melakukan lobi-lobi yang bertujuan mempnegaruhi kebijakan atau kewenangan.

Dari sedikit penjelasan tersebut kiranya dapat dimengerti bagaimana transisi demokrasi berlangsung dengan salah satu poin pentingnya adalah adanya kebebasan informasi. Pengalaman yang terjadi di era orde baru memberi tekanan penting sebagai masukan bagi sebuah sistem politik Indonesia, selain karena pula disebabkan pengaruh gelombang demokrasi yang terjadi terutama di negaranegara maju, seperti Amerika. Hal ini kemudian dijawantahkan sebagai kehendak bersama sehingga kemudian lahirlah sebuah produk politik berupa jaminan akan adanya kebebasan informasi dan juga jaminan akan penggunaan hak tersebut bagi media.

\section{Islam dan Tentang Islam}

\subsection{Islam dan perdebatan media}

Paska serangan ke gedung WTC tahun 2001 silam menjadi titik balik bagi Islam dan dunia Islam yang mendapat sorotan secara luas oleh masyarakat dunia, terutama AS. Mereka meyakini betul bahwa serangan tersebut merupakan bentuk dari teror yang dilancarkan dengan dilatarbelakangi oleh keyakinan, setidaknya itulah yang selalu dipropagandakan oleh media-media di barat, terutama di AS. Benarkah demikian?

Sebuah pertanyaan, mengapa teroris membenci AS? Mengenai hal ini Fareed Zakaria, redaktur majalah newsweek edisi luar negeri mengungkapkan bahwa bukan karena kebencian terhadap perjuangan kebebasan, tidak pula karena iri hati atas kemakmuran yang diperoleh, dan sebagainya. Ada sesuatu yang lebih kuat yang bekerja sehingga menggerakkan rasa ingin membunuh sekaligus mati, bukankarena rasa rendah diri atau iri hati. Bagi Fareed, Usamah Bin Ladin memiliki jawabannya, yakni agama.
Bagi Usamah dan pengikutnya, ini adalah perang suci antara Islam dan dunia barat. Meski sekali lagi soal perjuangan seperti ini banyak ditolak oleh sebagian besar Muslim di dunia (Zakaria, 2005).

Perspektif media di dunia selama ini, terutama di AS, telah mengalami banyak distorsi dan mis-informasi mengenai Islam. Generalisasi terhadap perjuangan yang dilakukan atas nama jihad, oleh media barat sering diidentikkan dengan kekerasan, fundamentalis dan radikal. Dan propaganda ini terkesan mendekati kebenaran karena tak lepas dari peran media barat yang terus menerus menginformasikan kepada masyarakat dunia. Sehingga konsekuensi dari ini semua adalah pembenaran pula terhadap pembalasan dendam dan penyerangan dengan alasan memberantas teroris di berbagai belahan dunia. Kontradiksi seperti inilah yang hingga sekarang terus menjadi perdebatan, apakah Amerika benar-benar memerangi terorisme atau menjadikan Islam sebagai musuh bersama?

Nampak sumir untuk menjelaskan fenomena terorisme yang terjadi selama ini,terutama atas pandangan Amerika terhadap apa yang mereka lakukan selama ini untuk "memberantasnya". Reaksi yang berlebihan seringkali dilakukan oleh AS dengan alasan-alasan yang terkesan dibuat-buat. Tak pelak kondisi ini justru membangkitkan semangat anti Amerika, terutama yang terjadi di negara-negara berpenduduk Muslim. Mereka tidak suka dengan Pemerintah Amerika dan media Amerika yang terus menerus menebar kebencian terhadap Islam, meski di sisi lain mereka juga mengutuk keras tindakan terorisme.

Kenyataan kejanggalan ini pada akhirnya menggiring beberapa pihak di barat untuk membongkar esai-esai lama serta prasangka-prasangka kuno yang meramalkan sebuah "benturan peradaban" antara Barat dan Islam. Sejarawan Paul Johnson malah menyebutkan bahwa 
Tersedia Online di http://journal.unismuh.ac.id/index.php/otoritas

Otoritas : Jurnal Ilmu Pemerintahan, 6 (2), Oktober 2016, 107

pada dasarnya Islam adalah agama yang tidak toleran dan penuh kekejaman. Cendikia lain tidak setuju dan menunjukkan bahwa Islam mengutuk pembunuhan kaum yang tidak bersalah dan melarang tindakan bunuh diri. Selain itu, jika dilihat secara gamblang banyak pula negaranegara yang menunjukkan sikap lunak dan tidak anti Amerika. Negara Muslim terbesar di dunia, Indonesia, sampai krisis ekonomi baru-baru ini, telah mengikuti dengan seksama nasehat Washington atas ekonomi. Terdapat pula Pakistan dan Bangladesh yang memadukan Islam dan modernisasi. Meski kedua negara ini adalah negara miskin, namun keduanya teah mengangkat perempuan ke tampuk pimpinan tertinggi negeri tersebut, jauh sebelum negara-negara Barat melakukan hal yang sama (Zakaria, 2005).

Bisa dikatakan, Islam "diperkenalkan" dengan suatu situasi yang penuh konflik. Usaha anti Amerika yang disebarkan Usama dengan berlatar belakang agama, dipersonifikasi sebagai fenomena general agama Islam. Islam fundamental, Islam radikal, ekstrimis Islam, adalah istilah-istilah yang sering digunakan media barat kepada merekamereka yang berjuang menegakkan jihad atau bahkan sekedara memperjuangkan keadilan seperti yang terjadi di Palestina. Begitu halnya juga dengan istilah negara "poros setan" yang dialamatkan kepada Iran atas kebijakan mereka dalam pengayaan nuklir untuk energi. Dominasi media barat yang demikian besar tak pelak mempengaruhi cara pandang dunia terhadap Islam dan mereka yang memluk agama Islam. Sikap kebencian dan permusuhan terhadap Islam sering dilancarkan oleh media untuk menyudutkan Islam.

Menambahkan fakta bahwa media menciptakan ide-ide yang tidak akurat tentang Islam, media Barat juga sangat berpengaruh kepada khalayak dalam membuat stereotip Islam negatif, seperti pernyataan bahwa semua umat Islam fun- damentalis. Istilah "fundamentalis" sebenarnya adalah sebuah istilah yang ditafsirkan oleh media. Seorang fundamentalis, dalam kenyataannya, hanya mewakili muslim normal yang mengikuti agamanya. Fundamentalisme berarti suatu sikap, suatu usaha, atau gerakan yang sebuah ideologi, kelompok, atau agama berusaha untuk mempromosikan dalam kepercayaan yang mendasar. Walaupun media merasa tidak nyaman dengan kelompok-kelompok keagamaan, itu sangat berfokus pada "fundamentalisme Islam".

Sebagian besar dari laporan-laporan media yang berbicara tentang fundamentalisme Islam biasanya menggambarkan sebagian besar Muslim sebagai ekstremis. Hal ini menunjukkan bagaimana media ini bodoh, karena Islam secara khusus melarang semua bentuk-bentuk ekstremisme. Nabi Muhammad berkata, "Orangorang yang pergi ke ekstrem (dalam menjalankan agama mereka) dikutuk (oleh Allah)". Media yang paling sering menggambarkan Muslim "fundamentalis" bersujud diri di hadapan Allah dalam doa. Sebagai contoh, dalam edisi 4 Oktober of Time, tentara Muslim melakukan doa diperlihatkan dengan senjata. Tulisan di bawah gambar berkata, "Senjata dan doa pergi bersama-sama dalam pertempuran fundamentalis". Bagian yang dihilangkan para wartawan atau gagal untuk menyatakan adalah bahwa tentara muslim sedang berdoa di medan perang di Afghanistan. Common sense situasi berarti bahwa para prajurit harus tetap bersenjata di sepanjang waktu dalam kasus penyergapan setiap saat. Ini adalah contoh yang jelas dari media bias dan tidak akurat pelaporan.

Terorisme secara khas dapat dilihat sebagai perkembangan langsung ideologiideologi modern. Namun, kaum teroris fundamentalis Islam menyatakan berjuang atas dasar teologis; berlandaskan pada rujukan kitab suci dan sunnah, dan memberikan label Islam pada setiap operasi. Keseluruhan struktur ideologis 
Tersedia Online di http://journal.unismuh.ac.id/index.php/otoritas

Otoritas : Jurnal Ilmu Pemerintahan, 6 (2), Oktober 2016, 108

tersebut tampak seperti dijalin dari pendekatan terhadap tradisi, etnisitas, dan kedudukan sejarah lama dan baru, serta serangkaian rujukan bernada religious, sperti "kafir", "kaum musyrik", "perang salib", "syuhada", "jihad", dan sebagainya.

\subsection{Perspektif media tentang Islam : Amerika dan Indonesia}

Dalam rangka menekankan pentingnya energi alternatif bagi rakyat Amerika, Consolidated Edison (Con Ed) di New York meluncurkan iklan televisi di musim panas 1980. Cuplikan-cuplikan menampilkan para pemimpin negaranegara arab dan ingin menunjukkan keterkaitan antara Islam dengan minyak. Tanpa adanya penjelasan terhadap siapa sesungguhnya mereka, namun dengan cara kurang menyenangkan - istilah Edward Said - kita diberitahu bahwa mereka adalah orang-orang yang mengontrol minyak Amerika. Sebuah kesan untuk semakin membangkitkan perasaan marah, kebencian dan rasa takut rakyat Amerika. Perasaan inilah yang dimanfaatkan oleh Con Ed dalam iklan domestiknya. Ada dua hal mengenai iklan Con Ed ini. Pertama, Islam atau lebih tepatnya adalah citra Islam di dunia barat, khususya AS. Dan kedua, penggunaan citra tersebut di AS dimana hal ini berkaitan dengan cara-cara yang pada akhirnya mengungkap tentang bagaimana AS dan barat memperlakukan Islam (Said, 2002).

Sebagian besar media di AS mengkampanyekan tentang ketakutan terhadap Islam (Islamophobia). Mereka menilai bahwa Islam telah menimbulkan kesan yang menakutkan dan dianggap selalu menyebarkan potensi kekerasan. Padahal, Islamophobia atau anti Islamofasisme berarti bahwa sebagian besar kebijakan politik dan praktek-praktek AS tidak mungkin diinterpretasikan dengan alasan terang-terangan, betapapun pentingnya, seperti kesalahan keamanan yang terkait dengan fenomena teorisme, atau ancaman yang mungkin ter- jadi pada kondisi negara-negara Islam memiliki kekuatan yang menggetarkan berupa senjarah pemusnah massal atau teknologi modern sebagaimana yang terjadi pada Irak, Iran dan Pakistan. Bahkan ada ketakutan sebagaian negara terhadap Indonesia atas kepemilihan teknologi industri penerbangan dan yang lainnya, sebagaimana disadari oleh mantan Presiden BJ Habibie. Atau dicapainya independensi nyata di dalam kerjasama negara-negara Islam di dalam mengelola kekayaan alam dan potensi sendiri terutama sumbersumber minyak.

Sebuah citra negatif Islam menjadi lebih inheren dalam kebudayaan Barat, khususnya Amerika dari liputan media tidak akurat. Media membantu untuk membuat citra Islam kepada khalayak yang tidak curiga. Hegemoni media global Amerika membuat masyarakat dunia sering salah informasi tentang umat Islam melalui gambar-gambar di televisi, film layar, majalah, radio, dan komik strip di surat kabar, yang mempromosikan pesanpesan yang kuat di antara para penonton. Wartawan barat sering berkata bahwa muslim adalah teroris. Ini menjadi gambaran umum untuk orang umum bahwa semua muslim adalah teroris. Edward Said mengatakan bahwa Istilah Islam seperti yang digunakan saat ini tampaknya berarti satu hal yang sederhana, tetapi sebenarnya merupakan bagian fiksi, bagian label ideologis, bagian penunjukan minimal yang disebut agama Islam. Selama beberapa tahun terakhir, terutama sejak peristiwa di Iran menangkap perhatian Eropa dan Amerika begitu kuat, Oleh karena itu media meliputi Islam; mereka telah digambarkan itu, dicirikan itu, dianalisis itu, diberikan kursus instan di atasnya, dan karena mereka telah berhasil diketahui (Said, 2002).

Media Amerika berbeda dengan media di Inggris atau Perancis karena masyarakatnya juga sangat berbeda, audiensnya berbeda, organisasi serta kepentingannya juga berbeda. Setiap wartawan 
Tersedia Online di http://journal.unismuh.ac.id/index.php/otoritas

Otoritas : Jurnal Ilmu Pemerintahan, 6 (2), Oktober 2016, 109

Amerika harus menyadari bahwa negaranya adalah satu-satunya negara adikuasa yang memiliki kepentingan dan cara-cara tersendiri untuk mencapai kepentingan tersebut, yang tidak dimiliki oleh negara lain. Kebebasan pers sangat dihargai disana, baik dalam teori maupun dalam prakteknya. Namun, hampir semua wartawan AS meliput dunia dengan kesadaran tinggi bahwa perusahaannya adalah partisipan kekuatan Amerika, sehingga ketika diancam oleh negara lain, akan menjadikan kebebasan pers ditempatkan lebih rendah terhadap apa yang seringkali hanyalah menjadi ekspresi implicit berupa loyalitas dan patriotism, dari identifikasi nasional yang sederhana (Said, 2002).

Pemberitaan media Amerika tentang negara-negara asing (termasuk Islam), tidak saja menciptakan namun juga memperkuat kepentingan. Sudut pandang media bersifat sangat subjektif dan tentunya berdasarkan pada kepentingan rakyat Amerika. Media dapat melakukan segalanya, menampilkan segala bentuk sudut pandang, menyediakan segala hal yang eksentrik, hal-hal tak terduga, bahkan yang menyimpang dari kebiasaan. Akan tetapi pada akhirnya, karena mereka adalah lembaga yang melayani dan mempromosikan identitas perusahaan Amerika, mereka semua memiliki konsensus sentral yang sama dalam benak mereka. Kasus di Iran misalnya, bagaimana mereka membentuk berita, memutuskan apa yang menjadi berita, bagaimana ia bisa menjadi berita, dan lain sebagainya yang pada akhirnya menampilkan berita yang bias atau tidak masih menjadi perdebatan (Said, 2002).

Distribusi terluas dan tentunya memiliki pengaruh yang kuat dilakukan oleh beberapa organisasi, dua atau tiga jasa layanan kabel, tiga stasiun televisi, CNN, setengah lusin Koran harian, dua atau tiga majalah mingguan. Beberapa nama seperti CBS, Time, NewYork Times, $\mathrm{AP}$, mereka adalah media-media yang me- raih lebih banyak konsumen, membuat kesan lebih dalam, memperoleh materi berita lebih banyak dibanding mediamedia lain yang lebih kecil dan lebih miskin. Satu hal bahwa, masyarakat Amerika kurang memiliki kesempatan untuk melihat dunia Islam kecuali dengan cara-cara yang reduktif, secara paksa dan berkebalikan (Said, 2002).

Bagaimana dengan di Indonesia? Dengan dominansi keyakinan yang besar dan bahkan terbesar di dunia, Islam menjadi agama keyakinan bagi sebagian besar penduduk Indonesia. Konsekuensi dari ini semua adalah tidak ada pandangan yang kontradiktif terhadap Islam sebagai agama. Namun, ketika berbicara tentang kelompok-kelompok yang berjuang dengan cara yang ekstrim, maka umat Islam Indonesia memiliki pandangannya sendirisendiri. Ada yang setuju dan banyak pula yang tidak setuju. Yang setuju tentunya mereka juga memiliki persamaan pandangan dan memiliki perasaan yang sama atas ketidakadilan yang dilakukan oleh Amerika dan sekutunya, terutama terhadap negara-negara Islam, meski mereka kebanyakan dari yang setuju jarang yang berpikir akan dapat melakukan tindakan sejauh itu. Sementara yang tidak setuju beralasan bahwa cara seperti itu tidak ada di dalam Islam. Islam mengajarkan cara yang lebih santun dalam menyampaikan satu kebenaran dan harus melindungi orang-orang yang tidak bersalah.

Namun, di sisi lain secara jujur, kesan-kesan seperti ini juga karena dipengaruhi oleh media global yang dimiliki Amerika. Adanya pertentangan dan perdebatan cara pandang terhadap upaya yang dilakukan oleh kaum fundamentalis Islam merupakan bagian dari arus propaganda yang dikampanyekan Amerika untuk memerangi "terorisme". Pada tataran media Indonesia sendiri, kelatahan atas pemberitaan seperti ini tidaklah terlalu dominan. Meski terdapat satu atau dua pemberitaan, namun tidak secara frontal 
Tersedia Online di http://journal.unismuh.ac.id/index.php/otoritas

Otoritas : Jurnal Ilmu Pemerintahan, 6 (2), Oktober 2016, 110

melakukan identifikasi, terlebih dalam kerangka ingin menyebarkan kebencian. Media di Indonesia nampaknya agak menjauhi pemberitaan yang mengarah pada pemahaman teologis karena tentunya dikhawatirkan akan berpretensi kurang baik, terutama bagi media itu sendiri.

\section{Kesimpulan}

Sering media Barat menggambarkan Islam sebagai "Islam militan" atau "Islam fundamental" ancaman terhadap Barat. Hal ini ditegaskan oleh Edward Said yang menyatakan bahwa bagi masyarakat umum di Amerika dan Eropa saat ini, Islam adalah "berita" dari jenis yang sangat tidak menyenangkan. Media, pemerintah, ahli strategi geopolitik, dan walaupun mereka marjinal dengan budaya pada umumnya-pakar akademis Islam adalah semua dalam konser, Islam adalah ancaman bagi peradaban Barat. Sekarang ini tidak berarti sama dengan mengatakan bahwa hanya merendahkan atau rasis karikatur Islam dapat ditemukan di Barat ... Apa yang saya katakan adalah bahwa citra negatif Islam sangat jauh lebih menonjol daripada yang lain, dan bahwa gambar yang sesuai, bukan untuk apa Islam "adalah" ... tetapi untuk apa menonjol sektor masyarakat tertentu membawanya menjadi: Mereka sektor memiliki kekuatan dan kemauan untuk menyebarluaskan bahwa citra Islam tertentu, dan karena itu citra ini menjadi lebih menonjol , lebih hadir, daripada semua yang lain.

Dalam bukunya yang berjudul The Islamic Threat: Myth or Reality, states the question, John L. Esposito's bertanya sapakah Islam sebagai ancaman bagi Barat? Dia mengatakan kepada kita bahwa jawabannya terletak pada pandangan Barat. Dia mengatakan bahwa jika kekuatan Barat terus mempertahankan status tidak adil Timur Tengah atas nama yang ilusif atau sekilas stabilitas, Islam akan menjadi ancaman. Tapi kalau kekuatan Barat mulai menghargai keluhan legitimasi di Timur Tengah, Barat dan gerakan-gerakan Islam akan bergaul dengan damai.

Dengan sorotan media Barat dan beberapa sikap pemerintahan Barat, Barat adalah tempat di mana Islam adalah nama negatif. Media Barat telah berkontribusi banyak untuk citra negatif Islam ini. Sering media dan akurat menjelaskan gambaran salah tentang Islam dan manifestasi. Kadang-kadang tampaknya media menjadi bias terhadap Islam. Ketika media mendistorsi citra Islam, masyarakat umum cenderung percaya, karena media merupakan sumber informasi utama yang akan publik tentang Islam. Ini kebodohan yang terakumulasi Barat dari media membawa mereka ke dalam membuat stereotip tentang Islam dan mengaitkan semua Muslim dan Arab bersama-sama. Barat sering kali dilihat Islam sebagai "fundamental" "ekstremis" atau "diskriminatif", tetapi semua istilah ini mempunyai dimanipulasi, bias dengan sengaja karena perasaan dan secara tidak sengaja karena ketidaktahuan, oleh media untuk menampilkan citra negatif tentang Islam. Islam sebenarnya adalah agama yang damai dan adil yang paling sering tidak sesuai dengan laporan media.

Demokratisasi memberikan rekomendasi penting di dalam mencapai tata negara yang demokratis, yakni menjadikan media (pers) sebagai salah satu pilar penting di dalam dinamika politik. Dalam wujud yang sederhana, peran media harus mampu menjembatani kepentingan rakyat dan turut pula bertanggung jawab dalam melakukan transformasi dan perubahan di dalam masyarakat. Media (pers) tidak harus selalu memang vis a vis dengan penguasa, namun sedapat mungkin pula media tidak atau jangan terlalu dekat dengan penguasa. Sebab, jika sudah demikian, kecenderungan akan terjadi distorsi terhadap konten pemberitaan akan sangat besar. Media akanlebih mudah direduksi demi kepentingan penguasa tersebut. 
Tersedia Online di http://journal.unismuh.ac.id/index.php/otoritas

Otoritas : Jurnal Ilmu Pemerintahan, 6 (2), Oktober 2016, 111

\section{Ucapan Terima Kasih}

Ucapan terima kasih, penulis haturkan kepada Pimpinan Departemen Ilmu Pemerintahan, Fakultas Ilmu Sosial dan Ilmu Politik Universitas Padjajaran beserta rekan dosen atas dukungannya baik berupa dukungan materi maupun non materi, sehingga artikel ini dapat selesai.

\section{Daftar Pustaka}

Bey, Arifin. 2003. Beyond Civilizational Dialogue: A Multicultur Symbiosis in The Service of World Politics. Jakarta: Paramadina.

Budiardjo, Miriam. 2008. Dasar-Dasar Ilmu Politik. Jakarta: Pustaka Gramedia Utama.

Chilcote, Ronald. 2007. Teori Perbandingan Politik: Penelusuran Paradigma (terj). Jakarta: Raja Grafindo Persada.

Gaffar, Afan. 2000. Politik Indonesia: Transisi Menuju Demokrasi. Yogyakarta: Pustaka Pelajar.

Habermas, Jurgen. 1989. The Theory of Communicative Action, Vol. 2, terj. Thomas McCarthy, Boston Beacon Press.

Huntington, Samuel. 1975. Michel Crozier dan Joji Watanuki, The Crisis of Democracy: Report on Governability of Democracies to Trilateral Commission. New York University. New York.
Latif, Yudi. 2009. Requiem Dini, Krisis Finansial dan Krisis Demokrasi. Jurnal Prisma, LP3ES, Vol. 1.

Lay, Cornelis. 2006. Involusi Politik: EseiEsei Transisi Indonesia, PLOD UGM, Yogyakarta.

Mas'oed, Mohtar. 1994. Negara, Kapital dan Demokrasi. Yogayakarta: Pustaka Pelajar

Montesquieu. 1993. Membatasi Kekuasaan: Telaah Mengenai Jiwa Undang-Undang. Jakarta: Gramedia Pustaka Utama.

Said, Edward W. 2002. Covering Islam. Yogyakarta: Jendela.

Siregar, Ashadi. 2006. Etika Komunikasi. Yogyakarta: Pustaka Book Publisher.

Sudibyo, Agus. 2009. Rekolonisasi Ruang Publik: Anomali Dunia Penyiaran Pasca 2002. Prisma Vol 1, LP3ES.

Suhelmi, Ahmad. 2007. Pemikiran Politik Barat: Kajian Sejarah Perkembangan Pemikiran, Negara, Masyarakat dan Kekuasaan. Jakarta: Gramedia Pustaka Utama

Susilo, Taufik. 2009. Mengenal Amerika Serikat. Yogyakarta: Garasi. 